\title{
A Study on Temperature Estimation in Concrete Members After Fire
}

\author{
MASATOMO YOSHIDA, YOSHINORI OKAMURA and SHIGEKI TASAKA \\ Department of Building Physics \\ General Building Research Corporation of Japan \\ 5-8-1, Fujishirodai, Suita City, Osaka Pref., 565, Japan
}

\section{TOSHIKATSU SHIMODE}

Technica! Research Center

Kansai Thermal Insulating Ind. Co. Ltd.

2-2-35, Kamisakabe, Amagasaki City, Hyogo Pref., 661, Japan

\section{ABSTRACT}

This report describes a new method to deduce temperatures in concrete after fire. In this paper, the temperatures in fire-damaged concrete members were presumed, aiming at admixture responsive to thermal career. By measuring the ultraviolet absorption spectra of admixture, it was found that heated temperatures in concrete were possible to be presumed from absorbances. At the next stage of this study, heated temperatures in actually fire-damaged concrete were presumed by using this method. Moreover, the validity of this presumption method was verified by comparing the presumed temperatures with the actually measured ones in the firetested concrete members(floor and column). The influence of burning exhaust on this presumption method was also examined and it was found that there was no influence of the exhaust on the method by shaving off the surface layer of concrete.

KEYWORDS: concrete, fire-damage, admixture, UV spectrum, heated temperature, presumption method

\section{INTRODUCTION}

In Reinforced Concrete(RC) buildings, fires often continue longer within fire compartments and heavy damage is caused by the fires. In such cases, it is a very important matter whether the buildings are re-used or not and it depends on the degree of damage. When fire-damaged $R C$ buildings are investigated, it is very important to presume heated temperatures of concrete and steel in main structural parts and to diagnose the degree of damage of each member. At present, the methods of chemical analysis[1] and of theoretical calculation[2] etc. are recognized as the methods to presume heated temperatures in concrete. It is difficult to say that the above-mentioned methods are effective means in order to grasp heated 
temperatures more accurately. And therefore, the authors aimed at organic materials, that is, "concrete chemical admixture" (hereafter, admixture), which are contained in minute amounts in concrete and are responsive to thermal career. And by investigating thermal career of this admixture, the authors proposed the method to presume heated temperatures up to about $600^{\circ} \mathrm{C}$ under which concrete and steel bars can be re-used.

In this paper, the authors metioned a new method to presume heated temperatures in concrete. And by applying the method to case of $f$ ire, they have verified that the presumption method was proper. And then, they examined the influence of burning exhaust gas on this presumption method.

\section{THE PRESENT CONDITIONS OF FIRE-DAMAGE DIAGNOSIS FOR CONCRETE STRUCTURES}

\section{Assessment Method of Fire-Damaged RC Buildings}

In case of re-using the building after fire, it is neccesary to know the degree of damage to its each member more accurately by proper investigation. The assessment methods of fire-damaged $R C$ buildings at the present and their problems are classified as below.

(1) Visual observation on site[3],[4]----The surface condition of the total damaged structure is observed. Namely, discolorations, explosures, cracks, floatings, peelings and deflections etc. are observed on the concrete surface in detail. Only the rough degree of damage can be classified by this method.

(2) Schmidt hammer test[3],[5]-----The repulsive forces on exposed surface of concrete member are measured by Schmidt hammer test. Therefore, the compressive strengths are presumed on exposed surfaces, but the distribution of strengths at various depths cannot be presumed. Moreover, as the data of the compressive strengths on fire-damaged concrete by schmidt hammer test is insufficient, only the qualitative comparison of the degree of damage can be assessed.

(3) The neutralized test of concrete[3], [4]-----It is known that concrete is neutralized when it is heated over $500^{\circ} \mathrm{C}$. Phenolphthalein solution is sprayed on the peeled parts of the concrerte and the neutralized depths are measured. When long-cured concrete is fire-damaged, it is very difficult to judge whether the progress of neutralization is deterioration due to age or due to fire.

(4) The test of compressive strength on concrete core[3]-----Core samples are pulled out from fire-damaged concrete members and the residual compressive strengths are presumed by compressive tests. As the degree of damage changes depending on the depth in concrete members, the residual strength distribution at various depth cannot be assessed by this method.

(5) Ultrasonic method[3], [5],[6]-----The transmitting time through firedamaged concrete is measured by the ultrasonic method and the degree of damage is investigated. As only the average transmitting time of concrete members is known, the distribution of the damage at various depth is unknown.

When the above-mentioned methods $((1) \sim(5))$ are used, only the rough and surface degree of damage of concrete members can be judged and the exact degrees at 
various depths cannot be judged. Accordingly, in order to assess fire-damaged concrete more accurately, it is important to presume the heated temperatures of the internal concrete and stee 1 bars in the main structural parts accurately and to grasp the mechanical properties of concrete and steel bars corresponding to their heated temperatures.

Presumption Method of Heated Temperatures in Concrete

The methods to presume heated temperatures in concrete at the present are mainly as follows.

(1) The method of chemical analysis[1]-----Heated temperatures in concrete are presumed by neutralization, analyses of carbonic acid gas and free lime, and $X$ rays diffraction etc..

(2) The method of theoretical calculation[2]-----The dimensions, shapes, amounts of combustible materials(interior finishes and carrying materials etc.) and windows etc. in a fire room are establishd, the fire conditions are predicted, and the heated temperatures in concrete are calculated.

(3) The method of the actually fire-damaged condition-----The fire condition (fire time and fire maximum temperature attained) is presumed by the data of fire station, the combustibilities of materials in a fire room and the carbonized depth and speed of wood. The external heated temperatures are presumed by the discoloration condition of concrete. And inner heated temperatures are calculated.

The problems for above-metioned methods((1) ( 3$)$ ) are as follows.

For (1), the chemical changes of inorganic materials are occasionally brought back to the condition before fire by fire-fighting water.

For (2), as the condition before fire in the fire room is not often known, it is difficult to grasp the real fire condition accurately. The heated temperatures in concrete are widely different by fire time and fire maximum temperature. Therefore, it is important to grasp the accurate fire scale.

For (3), it is difficult to grasp the real fire condition accurately, too. Moreover, it is difficult to distinguish the delicate discoloration condition of concrete.

PROPOSAL OF A NEN METHOD TO PRESUME HEATED TEMPERATURE IN CONCRETE

\section{Adoption of UV Spectral Method}

At present, lignin sulfonic acid is mainly used as admixtures, and then use of naphtaline sulfonic acid is next to this. As these admixtures consist of organic compounds which have conjugated double bonds, it is considered that their degrees to absorb ultraviolet rays (namely, absorbance A) are very big. Concrete which is composed of mainly inorganic matter is not perceived to absorb ultraviolet rays. Accordingly, aiming at admixture, as its quantative analysis is possible, the authors adopted UV spectral method as analysis one. The law of absorbance is presented in the following equation(1).

$A=\log (1 / T)$ 
$=a \cdot c \cdot 1$

where,

$\mathrm{T}$ : transmission factor $\left(=\mathrm{I}_{2} / \mathrm{I}_{1}\left(\mathrm{I}_{1}\right.\right.$ is incident intensity, $I_{2}$ is transmission

intensity),

a:absorption coefficient $(1 / \mathrm{cm})$,

c:concentration, and

l:thickness of absorption cell $(\mathrm{cm})$.

specrophotometer(UV-200) is used for measuring.

Characteristic of UV Spectra on Concrete

The differential thermal analysis(DTA) and differential thermogravimetry analysis(TGA) were measured in order to examine thermal properties of lignin sulfonic acid admixture. The results are shown in Fig.1. Weight loss by exothermic process begins at about $200^{\circ} \mathrm{C}$ and ends at $500 \sim 600^{\circ} \mathrm{C}$. The reason for this phenomenon is considerd to be that thermal cracking reaction of admixture causes from $200^{\circ} \mathrm{C}$ and almost ends at $500 \sim 600^{\circ} \mathrm{C}$.

Fig. 2 shows the relations between wave lengths and absorbances(hereafter, absorption curves) of $\mathrm{UV}$ spectra by $100^{\circ} \mathrm{C}$ from $110^{\circ} \mathrm{C}$ to $700^{\circ} \mathrm{C}$ on lignin sulfonic acid admixture. The absorbance at $110^{\circ} \mathrm{C}$ shows peak at wave length of $340 \mathrm{~nm}$. With the rise of temperature, absorbances reduce over all wave lengths. And they don't reduce over $500^{\circ} \mathrm{C}$.

As concrete usually contains admixture, absorption curve of concrete is influenced by UV spectral property of admixture as known from the comparison of $F$ ig.2 and Fig.3.

From Fig.3, the absorbances at wave length of $260 \mathrm{~nm}$ were considered to be relative with heated temperatures and were adopted in this presumption method.

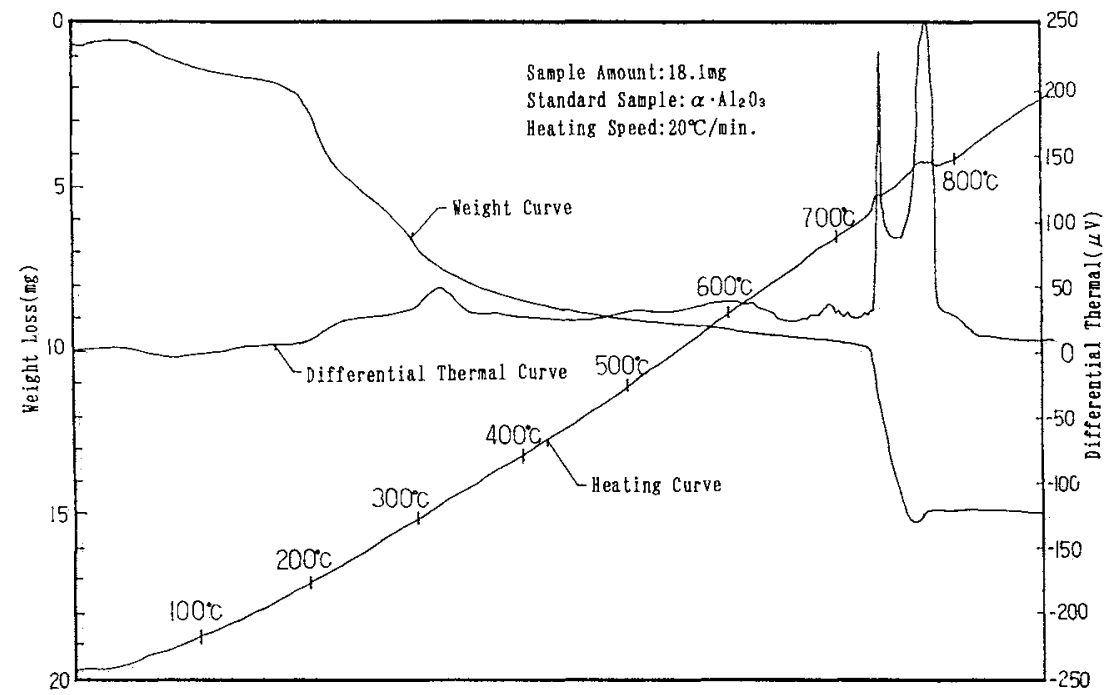

FIGURE 1. Results of DTA and TGA for lignin sulfonic acid. 


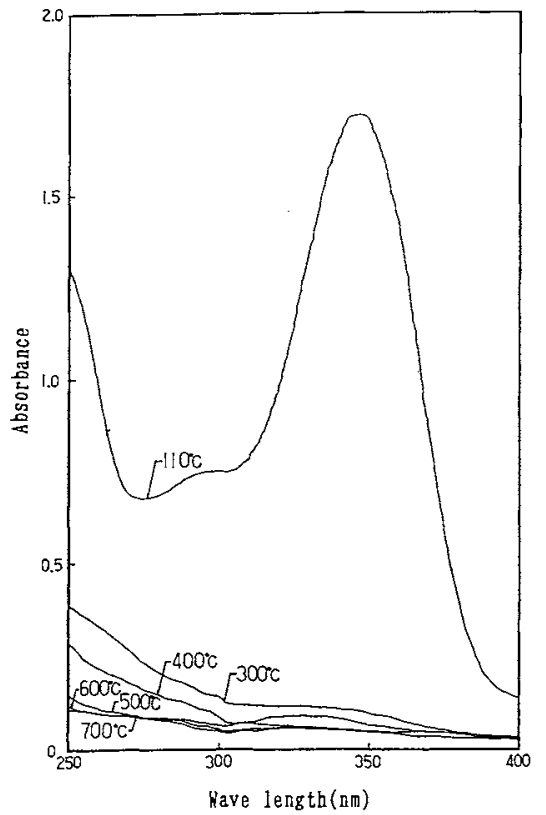

PIGURE 2. Absorption curves (case of lignin sulfonic acid admixture).

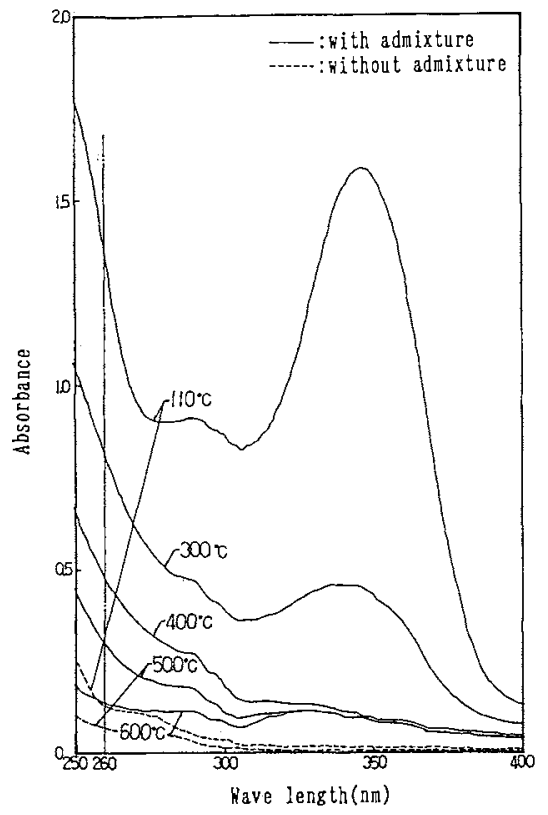

FIGURE 3. Absorption curves (case of concrete).

The absorption curves at $110^{\circ} \mathrm{C}$ and $500^{\circ} \mathrm{C}$ of concrete without admixture are shown in Pig.3, too. The absorbance of this concrete at $110^{\circ} \mathrm{C}$ is different from the one of concrete with admixture and doesn't show peak. Moreover, for the Iatter concrete, with the rise of temperature, absorbances slightly reduce.

\section{EXPERIMENTS ON PRESUMPTION METHOD}

\section{Experiment Method}

It was examined how influence the differences in contained amounts of admixture and cement paste gave on the measured results of UV spectra.

Method to Make Test Solutions for Measurement. Test specimen(both width and length: $300 \mathrm{~mm}$, height: $40 \mathrm{~mm}$ ) was made from concrete according to mix proportion (weight ratio:cement(normal portland) 100, water 50, fine aggregate(sand) 250 , coarse aggregate(crushed stone) 360 , admixture(air-entraining agent) 0.25 and 0.5 ), using lignin sulfonic acid as admixture. Procedures to make test solutions are shown in following 1) 4).

1) Test specimen air-cured for over 7 days was cut to test pieces(width:40mm, 
length: $150 \mathrm{~mm})$.

2) Test pieces were heated at each temperture $\left(110^{\circ} \mathrm{C}, 300^{\circ} \mathrm{C}, 400^{\circ} \mathrm{C}, 500^{\circ} \mathrm{C}\right.$ and $600^{\circ} \mathrm{C}$ ) for 60 minutes in electric furnace.

3) After heated, test pieces were crushed to the limit that crushed stones remained as they were. The parts through screens of 10 mesh and 35 mesh were finely crushed to the diameter of $5 \sim 10 \mu \mathrm{m}$ by vibration mill in order to examine the influence of difference in contained amounts of cement paste.

4) After test sample $(25 \mathrm{~g})$ was added by pure water $(100 \mathrm{ml})$ and it was boiled for 120 minutes, it was filtered by means of suction using $5 \mathrm{C}$ filter paper. And filter liquid was used as test solution.

Factors of test samples are additional ratios of admixture $(0.25 \%$ and $0.5 \%)$ to cement and sizes of screen(10 mesh and 35 mesh). Kinds of test samples are four (two factors by two elements).

Measurement of UV Spectra. IV spectra for test solutions at each heated temperature were analyzed using spectrophotometer, and their absorption curves were grasped.

\section{Test Results and Discussions}

From the measured results of absorption curves for each test solution, the relations between heated temperatures and absorbances at wave length of $260 \mathrm{~nm}$ are shown in Fig.4. Their relations from $110^{\circ} \mathrm{C}$ to $500^{\circ} \mathrm{C}$ became almost linear. over $500^{\circ} \mathrm{C}$, as admixture perhaps dissolves thermically and remaining concentration of thermal dissolution is smaller, absorbance is considerd to become constant.

\section{Examination on Improvement of Precision in Presumption}

The relations between heated tempertures and absorbances are considered to be slightly apart from the linear relation as known from Fig.4, because the precision in making test solutions was not very good. Three points shown in following a) c) were regarded to be the causes.

a) White-muddy state of the extracted solution by carbonic acid-----Calsium carbonate $\left(\mathrm{CaCO}_{3}\right)$ insoluble in water is made by reaction between Calusium ion $\left(\mathrm{Ca}^{2+}\right)$ of cement soluble in the extracted solution and Carbonic acid gas $\left(\mathrm{CO}_{2}\right)$ in air, and the extracted solution becomes muddy. Therefore, absorbance increases.

b) Adosorption of admixture to cement-----As admixture adsorbs cement, the extraction effiency of admixture drops and the concentration of admixture in the extracted solution becomes weak. Therefore, absorbance reduces.

c) Picked amount of test sample----As picked amount of test sample is more, amount of cement in test sample increases and the the extraction effiency of admixture drops. Therefore, absorbance reduces by the same reason as b).

Consequently, the improvement of precision in experiment was examined here, and following methods were adopted in order to remove three causes above mentioned. 
For a), the extracted solution was acidfied by hydrochloric acid(pH1.6), $\mathrm{CaCO}_{3}$ insoluble in water was dissolved. Therefore, muds were removed.

For b), after same solution was extracted by boiling repeatedly in order to improve the efficiency of boil extraction by water, total absorbances of first and second extracted solutions were adopted as absorbance.

For c), samples changed from 1 gram to 25 grams were extracted by boiling respectively. Absorbances per sample quantity of 1 gram at wave length of $260 \mathrm{~nm}$ were measured and the results are shown in Fig.5. As the result, the quantity of 3 grams where absorbance became maximum was adopted as sample quantity.

By using the above three methods, the accurate relation between heated temperatures and absorbances was grasped as shown in Fig.6, and the improvement of precision in presumption could be attempted.

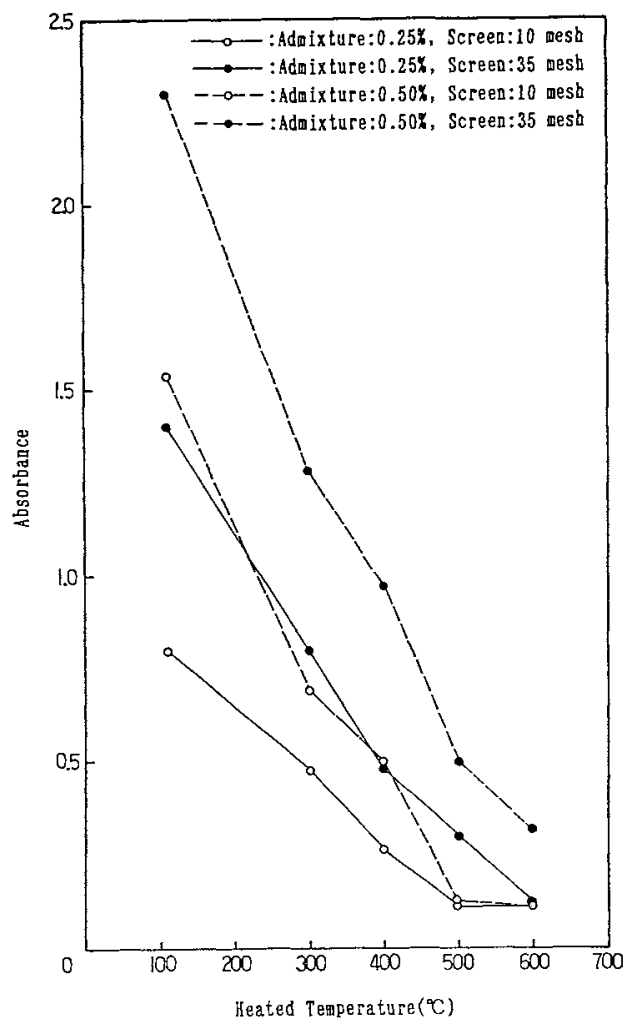

FIGURE 4. Relations between heated temperatures and absorbances.

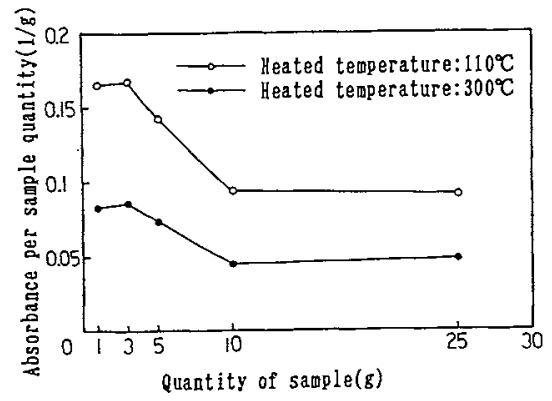

FIGURE 5. Absorbances per sample quantity of $1 \mathrm{~g}$.

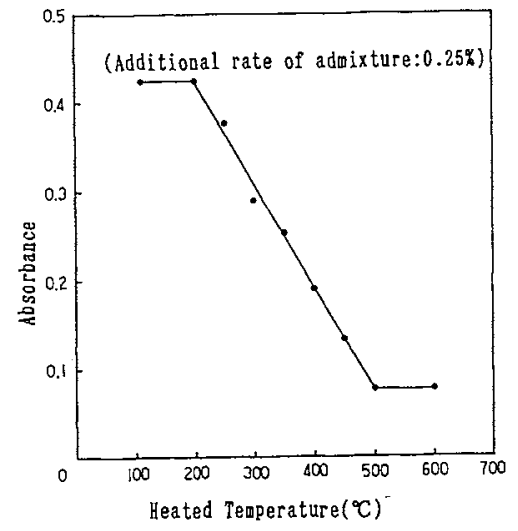

FIGURE 6 . Relation between heated temperatures and absorbances (case of concrete test specimen). 


\section{APPLICATION OF PRESUMPTION METHOD TO FIRE}

Concrete test specimens were cut off from the RC building which was actually suffered from fire-damage and brought to our laboratory. Then, heated temperatures of specimens were tried to be presumed. The fire occured at the roof of this building under construction, and parapets of the roof were exposed to the fire. For the case of this fire, heated temperatures of the parapets were presumed. The procedures and the test results are described as follows.

\section{Presumption Method}

Concrete cores(diameter: $10 \mathrm{~cm}$, length: $15 \mathrm{~cm}$ ) were cut off from the most firedamaged parts ( 2 points) and undamaged part( 1 point) of the parapets. At the first stage of presumption, UV spectra of an undamaged concrete core were measured to obtain the relation between heated temperatures and absorbances at wave length of $260 \mathrm{~nm}$. The obtained calibration curve is shown in Fig.?. The equations (2) (4) which are used to presume heated temperatures are derived from the calibration curve.

a) when $A=A_{h} \quad T \leqq 200$

b) when $A_{h}>A>A_{1} \quad T=\left\{\left(3 A+2 A_{1}-5 A_{n}\right) /\left(A_{1}-A_{n}\right)\right\} \times 100$

c) when $A=A_{1}$

$\mathrm{T} \geqq 500$

where,

A :absorbance of the fire-damaged sample,

$A_{n}$ :absorbance of the undamaged sample at normal temperature,

A : bsorbance of the aundamaged sample at $500^{\circ} \mathrm{C}$, and

T : heated temperature $\left({ }^{\circ} \mathrm{C}\right)$.

After the calibration curve was obtained, fire-damaged concrete cores were cut out every $4 \mathrm{~cm}$ from the surface to the inner part and three test specimens were taken from each core. JV spectra of these specimens were measured, and the heated temperatures were presumed using the equations $(2) \sim(4)$.

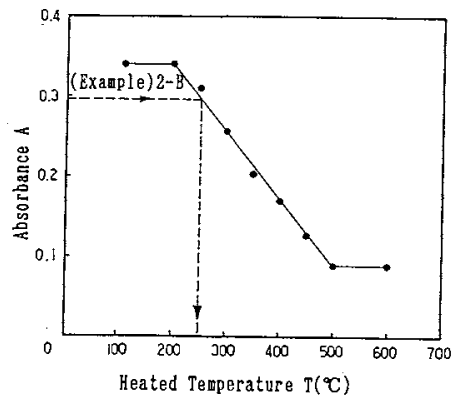

FIGURE 7. Relation between heated temperatures and absorbances

(case of concrete in a RC building).
TABLE 1. Presumed tempertures and compressive strengths of concrete.

\begin{tabular}{|c|c|c|c|c|c|}
\hline classification & \multicolumn{2}{|c|}{$\begin{array}{c}\text { sample } \\
\text { No. }\end{array}$} & $\begin{array}{l}\text { presumed } \\
\text { depth (cm) } \\
\text { (from surface) }\end{array}$ & $\begin{array}{l}\text { presumed } \\
\text { temperature } \\
\left({ }^{\circ} \mathrm{C}\right)\end{array}$ & $\begin{array}{l}\text { compress ive } \\
\text { strength } \\
\text { (MPa) }\end{array}$ \\
\hline \multirow{2}{*}{$\begin{array}{l}\text { Fire-danaged } \\
\text { part }\end{array}$} & 1 & $\begin{array}{l}A \\
B \\
C\end{array}$ & $\begin{array}{r}2 \\
6 \\
10\end{array}$ & $\begin{array}{l}275 \\
225 \\
225\end{array}$ & 21.6 \\
\hline & 2 & $\begin{array}{l}A \\
B \\
C\end{array}$ & $\begin{array}{r}2 \\
6 \\
10\end{array}$ & $\begin{array}{l}260 \\
250 \\
225\end{array}$ & 22.3 \\
\hline Undamaged part & \multicolumn{2}{|c|}{3} & - & - & 23.3 \\
\hline
\end{tabular}


The results of presumed temperatures and compressive strengths are shown in Table 1. Inner heated temperatures were presumed to be about $250^{\circ} \mathrm{C}$ from the result of absorbance as shown in Pig.7. Presumption of the inner temperatures is considered to be proper from the following discussions 1) and 2).

1) As the surface of fire-damaged concrete turned light brown, external heated temperature was presumed to be about $500^{\circ} \mathrm{C}[2]$. The inner heated temperatures are considered to be usually lower than the external one.

2) Compressive strengths of fire-damaged parts are almost similar to that of undamaged part. Dropping of compressive strength is not recognized from normal temperature to $300^{\circ} \mathrm{C}[7]$.

\section{VERIFICATION OF PRESUMPTION METHOD}

The validity of this presumption method was inspected by the fire tests of a column and a floor, and the presumed temperatures were compared with the known temperatures in concrete samples of the column and the floor. The results are described as follows.

\section{Case of Column}

Fig. 8 shows the results of heating temperatures(according to JIS A 1304) and inner temperatures for a Steel Reinforced Concrete(SRC) column. The cross section is shown in Fig.9. After the unheated concrete parts cut off from the column were heated at $110^{\circ} \mathrm{C}$ and $500^{\circ} \mathrm{C}$, the absorbances at wave length of $260 \mathrm{~nm}$ were obtained by UV spectral analyses. As the result, the absorbances at $110^{\circ} \mathrm{C}$ and $500^{\circ} \mathrm{C}$ were 0.254 and 0.059 respectively. The heated concrete part from the surface to the position of steel bars(its cover thickness:about $7 \mathrm{~cm}$ ) was cut off from the column. From the result of UV spectral analysis for the sample, its absorbance was 0.059 . Judged from the equations $(2) \sim(4)$, heated temperature of the sample was presumed to be over $500^{\circ} \mathrm{C}$. The maximum measured temperature of steel bars by thermocouple was $640^{\circ} \mathrm{C}$. Accordingly, the range of presumed temperature is considered to be proper.

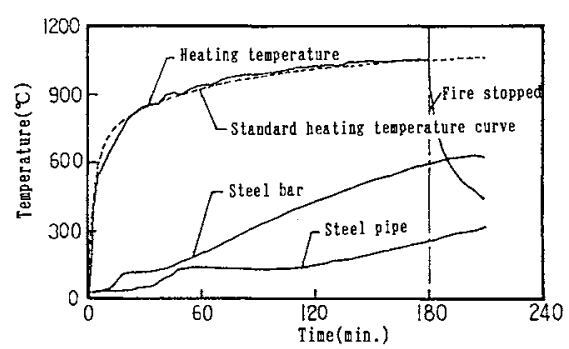

FIGURE 8. Measured results of temperatures in a column.

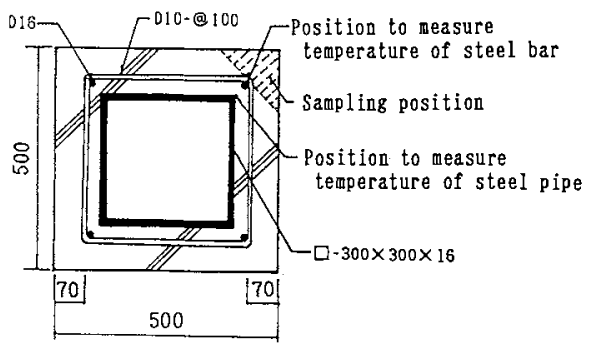

FIGURE 9. Cross section of a column (unit of measure:mm). 
The under side of a concrete floor(thickness: $19.5 \mathrm{~cm}$ ) was heated at constant $900^{\circ} \mathrm{C}$ for 4 hours. Distribution of inner maximum temperatures is shown in Fig. 10 . Unheated parts of concrete were heated at each temperature by $100^{\circ} \mathrm{C}$ from $110^{\circ} \mathrm{C}$ to $600^{\circ} \mathrm{C}$. Relation between heated temperatures and absorbances was derived from UV spectral analysis of each temperature. The relation used as calibration curve is shown in Fig.11. In the next place, concrete samples were cut off from 2 points shown in Fig.10. UV spectra of the samples were measured and their heated tempertures were presumed using the equations (2) (4). As the result, the temperature of sample (1) derived from the distribution as shown in Fig. 10 was $220^{\circ} \mathrm{C}$ and its presumed temperature was $220^{\circ} \mathrm{C}$. For sample (2), the former was $260^{\circ} \mathrm{C}$, and the latter was $255^{\circ} \mathrm{C}$. Consequently, the presumed temperatures were recognized to be almost in agreement with the temperatures derived from the distribution.
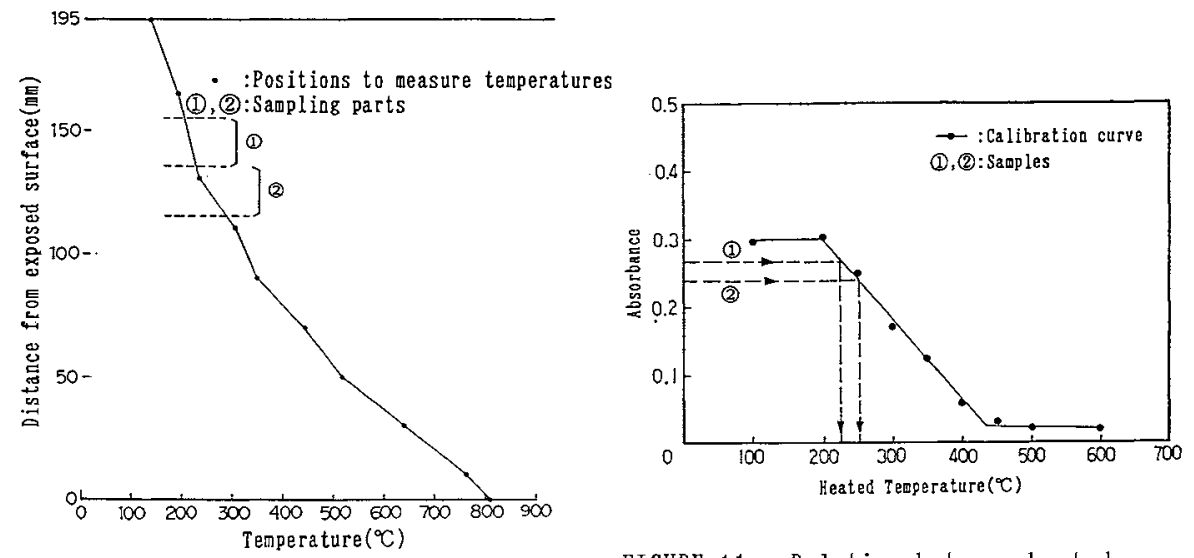

FIGURE 10. Distribution of maximum temperatures in concrete.

FIGURE 11. Relation between heated temperatures and absorbances (case of concrete in a floor).

\section{INFLUENCE OF BURNING EXHAUST ON PRESIMPTION METHOD}

When combustible materials and interior finishes were burnt in a fire room, it was investigated whether the organic compounds contained in burning exhaust gas penetrated into concrete members and influenced this presumption or not. The results are described here. Many kinds of organic materials were stuck on one side of each concrete test specimen(both width and height:40mm, length:150mm). Specifications of each concrete test specimens are shown in Table 2. After all test specimens were heated at $500^{\circ} \mathrm{C}$, stuck materials of test specimens were removed. Each surface layer(thickness:about $1 \mathrm{~mm}$ ) of concrete on the stuck side was shaved off. UV spectrum of each test specimen was measured. The results of absorbances at wave length of $260 \mathrm{~nm}$ for each specimen are shown in Table 2. The difference of absorbances among each specimen is scarcely recognized. In the extent of these results, it is considered that exhaust gas scarcely penetrates into concrete.

When burning exhaust gas was soluble in sprinkled water by fire fighting, it 
was studied whether the solutions penetrated into concrete and influenced this presumption method or not. Factor of water permeability $k_{c}$ of concrete is supposed to be under $2 \times 10^{-10} \mathrm{~cm} / \mathrm{sec}$ in extent of usually used water-cement ratio( $\left.40 \% \sim 70 \%\right)$ [8]. Unless defects(e.g. cracks and rock pockets etc.) are there, only a little water is considered to penetrate into concrete even for very long time.

Accordingly, if the surface layer of concrete is shaved off, the burning exhaust gas is not recognized to influence this presumption method.

TABLE 2. Specifications and absorbances of test specimens.

\begin{tabular}{|c|c|c|c|c|c|c|}
\hline \multirow{2}{*}{$\begin{array}{l}\text { specimen } \\
\text { symbol }\end{array}$} & \multicolumn{3}{|c|}{ organic materials } & \multicolumn{2}{|c|}{ adhesives } & \multirow[b]{2}{*}{ absorbance } \\
\hline & $\begin{array}{l}\text { material th } \\
\text { name }\end{array}$ & $\begin{array}{l}\text { thickness } \\
\qquad(\mathrm{mm})\end{array}$ & $\begin{array}{l}\text { using } \\
\text { amount } \\
\left(\mathrm{g} / \mathrm{m}^{2}\right)\end{array}$ & $\begin{array}{ll}\text { material } & \text { pa } \\
\text { name } & \text { am }\end{array}$ & $\begin{array}{l}\text { painting } \\
\text { amount } \\
\left(\mathrm{g} / \mathrm{m}^{2}\right)\end{array}$ & \\
\hline A & $\begin{array}{l}\cdot \text { vinyl } \\
\text { chloride }\end{array}$ & 0.6 & 733 & $\begin{array}{l}\cdot \text { vinyl } \\
\text { chloride }\end{array}$ & 80 & 0.070 \\
\hline B & $\begin{array}{l}\text { - soft } \\
\text { polyurethane } \\
\text { foam }\end{array}$ & 30 & 433 & $\begin{array}{l}\text {-polyurethane } \\
\text { system } \\
\text { (one liquid) }\end{array}$ & 40 & 0.071 \\
\hline $\mathrm{C}$ & $\begin{array}{l}\text {-polystyrene } \\
\text { foam }\end{array}$ & 30 & 820 & $\begin{array}{l}\cdot \text { vinyl } \\
\text { acetate } \\
\text { system }\end{array}$ & 90 & 0.069 \\
\hline D & $\begin{array}{l}\text { - water } \\
\text { acrylic } \\
\text { sealing }\end{array}$ & $\longrightarrow$ & 2000 & • nопе & - & 0.095 \\
\hline $\mathrm{E}^{*}$ & $\cdot$ bone & - & $\longrightarrow$ & $\cdot$ nопе & - & $\begin{array}{l}0.070 \text { (surface) } \\
0.051 \text { (inner) }\end{array}$ \\
\hline
\end{tabular}

(note)1.The part of concrete is the same for each test specimen.

2 *: test specimen with only concrete

\section{CONCLUSION}

In this paper, a new method to presume heated temperature in concrete was proposed and it was found that the presumption method was available. Conclusions which were got from the results of this study are summarized as follows:

(1) Heated temperatures from normal temperature to $600^{\circ} \mathrm{C}$ in concrete can be presumed by using UV spectral method.

(2) As the application results of the presumption method to an actually firedamaged $R C$ building, the reasonable heated temperatures were obtained, and the usefulness of the method was confirmed.

(3) As the results of fire tests on a column and a floor, the measured temperatures by fire tests agreed with the presumed temperatures by this method, 
and this presumption method was found to be proper.

(4) As this presumption method is aimed at organic compound, it was investigated whether burning exhaust gas(mainly organic compound) in a fire room gave any influence on the method or not. As the result, it was found that if the surface layers of concrete are shaved off, the exhaust gas scarcely influenced the method.

Hereafter, as more fire tests on each member shall be done, the validity of this presumption method will be further examined. For influence of burning exhaust gas, the quantities of combustible materials in a fire room will be assumed in detail, and the influence will be examined at each heated temperature besides $500^{\circ} \mathrm{C}$ used in this study. Moreover, as the data at fire sites will be accumlated, the simpler method adapted to the sites will be examined.

\section{REFERENCES}

1. Kishitani,K. and Mori,M., "The Degree of Fire-Damage and Presumption of Heated Temperature on Fire-Damaged RC Buildings" (in Japanese), Fire(Kasai), 85, 8-20, JAFSE, 1972 .

2. Nagatomo,M., Rimura,K., Ohmori,N., Yahiro,T., Muta,K., Takahashi,T. and Matsuzaki,Y., Strength Diagnosis and Its Comnterplan of the Fxisting Building(in Japanese), Kajima Co. Ltd., 1978.

3. Schneider,J., "Repairability of Fire Damaged Structures (CIB H14 Report)", Fire Safety Journa1, 16, 1990.

4. Matsui,Y., Durability Diagnosis and Its Measures of Structure(in Japanese), Shokokusha Co. Ltd., pp.151-152, 1976.

5. Nasser,K. and Al-Manaseer,A., "Comparison of Nondestructive Testers of Hardened Concrete" , ACI Material Journa 1, pp.374-380, 1987.

6. Fu,S.,Ide,M. and Sato,H., "A Study on Measurement of Degree of Fire-Damage in Concrete by U1trasonic Method" (in Japanese), Meeting for Reading Research Papers of JAFSE, pp.54-57, 1992.

7. Furumura,F., “Concrete and Heat(2)" , Concrete Journa1, 17: 9, 53-61, JCI, 1979 .

8. Maruyasu,T. and Mizuno, S., Concrete Engineering, Lecture of Civil Engineering 16 (in Japanese), Corona Co. Ltd., pp.124-127, 1970. 